\title{
Apoptosis and Apoptosis Modulators in Myeloid Leukemia
}

\author{
Maha Abdullah and Zainina Seman \\ University Putra Malaysia \\ Malaysia
}

\section{Introduction}

Acute myeloid leukemia (AML) is one of the most common types of leukemia in adults (American Cancer Society, 2010) however overall survival rate remain poor despite advancement in treatment modality.

Since the last 50 years, systemic chemotherapy has greatly improved outcome in many types of cancers. The use of continuous infusion Arabinosylcytosine (Ara-C) combined with another agent, usually an anthracycline or anthracenedione, the " $3+7$ " regimen, has been the backbone of induction therapy for AML cases (Yates et al., 1973). An attempt to add other drugs (Preisler et al., 1987) and intensification of the Ara-C dose (Schiller et al., 1992; Weick et al., 1996) to this approach has achieved some degree of success. Currently more work is attempted at improving patient outcome by intensifying the doses of anthracyclines (Lowenberg et al., 2010a) or by adding targeted therapies like gemtuzumabozogamicin (Lowenberg et al., 2010b; Nabhan et al., 2005).

For consolidation therapy, the use of Ara-C with or without other agents has been employed to maintain remission and cure. Allogeneic hematopoietic cell transplantation (HCT) based on initial cytogenetic (Cornelissen et al., 2007; Koreth et al., 2009) and molecular studies (Castaigne et al., 2004) have been proposed as an alternative consolidation therapies.

Induction therapy aims to produce complete remission (CR) defined as a marrow with less than $5 \%$ blast, a neutrophil count greater than $1000 / \mathrm{mm}^{3}$ and a platelet count greater than $100,000 / \mathrm{mm}^{3}$ (Cheson et al., 2003). Majority of younger patients (65-75\%) will achieve CR after receiving induction treatment while CR in elderly group is much lower (40-50\%).

Patients who do not respond to induction treatment display chemotherapy resistance (Estey et al., 1996). In trials done by the Southwest Oncology Group (SWOG), resistant disease was found in about 33\% (patients younger than 56 ) out of 404 patients' enrolled into the studies, $62 \%$ for patients in between 56-65 year old, $61 \%$ for patients between $66-75$ years old and $57 \%$ for age more than 75 year old (Frederick et al., 2006).

Resistance is also common at relapse (Estey et al., 1996). Relapse itself could be due to resistance to treatment in a subgroup of leukaemic cells which survived induction therapy despite CR. Patients usually relapse within two to three years after achieving CR. 


\section{Multi-drug resistance protein as a mechanism of drug resistance}

Development of drug resistance is a major problem in AML therapy. It will eventually occur in most haematological malignancies treated with chemotherapy. Classically, drug resistance is divided into extrinsic and intrinsic (Jean-Pierre et al., 2003). Extrinsic resistance (host factors) refers to the inability of the drug to reach the tumour cell. It occurs when the bioavailability of the oral form varies from patient to patient like poor absorption resulting in low serum levels.

Intrinsic (cellular) resistance is due to properties of the tumour cell. It can be classified as simple resistance, when cells are resistant to only one particular drug, or as multidrug resistance (MDR) when cross resistance is observed among chemotherapeutic drugs with different biochemical targets. Multidrug resistance is more common than simple resistance and it can be due to several mechanisms. The most common pharmacological mechanism involved is due to an active efflux of drugs from the tumour cells or enhanced drug metabolism which prevented the drug from reaching its target in the nucleus.

The most important protein described in MDR cells is P-glycoprotein (P-gp), a transmembrane energy-dependent drug efflux pump, which is most efficient at transporting naturally occurring substances. It is encoded by the MDR1/ABCB1 gene and belongs to a superfamily of $\mathrm{ABC}$ (ATP binding cassette) transporters. P-gp expression in AML at initial presentation has been reported to be $20 \%$ to $40 \%$ (Motoji T et al., 2000). Increase in P-gp expression in leukaemic cells causes reduced intracellular concentration of cytotoxic drugs. There are many drugs used in AML that are transported by P-gp including anthracyclines and anthracenediones like daunorubicin and mitoxantrone, the vinca alkaloids (vincristine and vinblastine) and the epipodophyllotoxins (etoposide and teniposide).

Other $A B C$ transport proteins that have been implicated in MDR include the multi-drug resistance associated proteins (MRP1/ABCC1) and the breast cancer resistance protein (BCRP/ABCG2). All these proteins are not unique to drug resistance cells but expressed in tissue with excretory and secretory functions. However, many studies have found that overexpression of these proteins correlate with poor treatment response (Damiani et al., 2010; Bendarra et al., 2005).

A non-ABC protein, found widely expressed in P-gp negative multidrug resistant cancer cell termed initially as lung resistance related protein (LRP) and now known as major vault protein (MVP) also has been implicated in drug resistance mechanism (Izquierdo et al., 1996; Huh et al., 2006). This protein is involved in bidirectional transportation of a variety of substrates between nucleus and cytoplasm. It is present in many cells and seems to be upregulated in cancer cells and has been found to be an adverse prognostic factor in AML (Styczynski et al., 2007). The expression of P-gp (Leith et al., 1999), MRP and LRP in AML was also found to correlate with advanced age ( $>60$ years) and high white cell count (van delHeuvel et al., 2007). It also correlates with high risk of relapse (Daniela et al., 2007).

There have been extensive trials conducted on AML therapy to circumvent drug resistance like reversion of P-gp, targeted agents against DNA replication and repair, cell cycling and apoptosis.

With the extensive knowledge on P-gp efflux mechanism and its contribution to drug resistance in AML, quinine and cyclosporine were tested to reverse the P-gp action. However, these substances did not significantly improve the response rate in AML (Eric et al., 2003; Solary et al., 1996; Liu et al., 1998; Tallman et al., 1995). Combination of tetrandrine, a potent inhibitor of the MDR-1 efflux pump, with induction therapy also showed no 
significant difference in response between P-gp positive and P-gp negative patients (Wen et al., 2006). Nevertheless, an early study revealed by using P-gp reversal modulators, the emergence of drug resistance could be prevented (Futscher et al., 1996). However, a recent randomized phase III trial involving 302 newly diagnosed AML patients, evaluated the effect of P-gp inhibitor valspodar (PSC-833) showed no difference in overall disease survival (Jonathan et al., 2010). Similar result was obtained in another phase III randomized trial involving poor risk AML patients when valspodar was added in the induction therapy (Peter et al., 2004)

\section{Molecular 'signatures' in AML}

AML is characterized by a high degree of heterogeneity with respect to chromosome abnormalities, gene mutations and expression of multiple genes. The heterogeneous nature of AML has significant clinical impact as there are marked differences in survival following intensive chemotherapy (explained in detail elsewhere in this book). The World Health Organization (WHO) classifies AML by cytogenetics, morphology, immunophenotype and clinical features (Swerdlow et al., 2008). Diagnostic karyotype emerges as the most significant prognostic factor as determined in multivariable analyses that take into account age, type of AML (de novo or secondary) and presenting white blood cell count (WBC), and accordingly provides the framework for current risk stratified treatment approaches (Grimwade, 2007). Nevertheless as cytogenetic and molecular genetic aberrations are not mutually exclusive the expression of downstream target genes that encode proteins involved in complex biologic networks are affected (Mrozek et al., 2009) and may alter predictability of standard prognostic markers. Microarray genome-wide gene-expression profiling (GEP) and microRNA-expression profiling assays have revealed AML signatures and may be readily applicable for diagnosis and outcome class prediction in AML (Mrozek et al., 2009). Many of the molecules involved are known mediators of signal transduction pathways and apoptosis.

\section{Apoptotic molecules in AML}

Apoptosis occurs principally via two separate yet interlinked signaling mechanisms: the extrinsic pathway, activated by proapoptotic receptor signals at the cellular surface (members of tumor necrosis factor, TNF, family), and the intrinsic pathway (members of Bcl-2 family), activated by mitochondrial signals from within the cell. These pathways converge through "effector" caspases, which orchestrate the apoptotic program. Nevertheless, each requires different initiation caspases to begin the process. The extrinsic pathway is activated by engagement of death receptors on the cell membrane. The death receptors involved in the extrinsic apoptotic pathway belong to the TNF receptor superfamily that include Fas (CD95 or Apo1), TNFR1 (TNF receptor 1), death receptor 3 (DR3/Wsl-1/APO-3/TRAMP/LARD), death receptor 4 (DR4/TRAIL-R1), death receptor 5 (DR5/TRAIL-R2) and DR6. These receptors are characterized by an intracellular death domain. There are also decoy receptors (i.e. DcR1 and DcR2) that contain no death domain or a truncated death domain and can bind ligand but cannot signal. Therefore, these decoy receptors function as antagonists to inhibit death ligand/death receptor-induced apoptosis. Binding of ligands, such as FasL, tumor necrosis factor-alpha (TNF-alpha) and TNF-related apoptosis-inducing ligand (TRAIL) to their respective membrane receptors Fas, TNF-R and 
TRAIL-R induces trimerization of the receptors and recruitment of adaptor proteins such as the Fas-associated death domain (FADD) to the death domain. This then recruits procaspase- 8 which then leads to the formation of the oligomeric death-induced signaling complex (DISC). DISC in turn promotes activation of caspase- 8 and a cascade of other caspase enzymes that culminates with cell death (reviewed in Elrod and Sun, 2008).

The intrinsic pathway is triggered by various extracellular and intracellular stresses, including growth factor deprivation, DNA damage, oncogene induction, hypoxia and cytotoxic drugs. Cellular signals originated by various mechanisms by these different stresses converge on a cellular target represented by mitochondria. Mitochondrial membrane permeability is controlled by pro-apoptotic (Bax, Bak, Bad, Bid, Bim, Bmf, NOXA, PUMA, Bok, Bcl-G, Bfk) and anti-apoptotic (Bcl-2, Bcl-L, Mcl-1, Bcl-w, A1) members of the Bcl-2 family, inducing or preventing heterodimerization of pro-apoptotic members. A series of biochemical events is induced that lead to damage of the outer mitochondrial membrane, with the consequent release of cytochrome $\mathrm{c}$ and other pro-apoptotic molecules, such as Smac/DIABLO, from the inner membrane into the cytosol enabling the formation of the apoptosome, a large molecular complex formed by cytochrome c, apoptotic protease activating factor 1 (APAF-1) and caspase-9, and massive activation of caspases. These proteins all play crucial roles for cell survival and the loss of any of these proteins causes major deregulation of survival of some cell types (reviewed in Ashkenazi and Herbst, 2008). Dysregulation of apoptosis plays an important role in the development of a variety of human pathologies, including cancer and particularly leukemia. The evasion of programmed cell death has been regarded as one of the six essential alterations in cellular physiology that dictate the growth of cancer cells and is a hallmark of virtually all cancers. Moreover, tumors that have alterations in proteins involved in cell death signaling are very frequently resistant to chemotherapy and are difficult to treat with chemotherapeutic agents that primarily act by inducing apoptosis (Testa et al., 2007).

Fas, DR4 and DR5 are generally expressed in both normal and malignant cells. An examination of patients with de novo AML revealed Fas was expressed on eight of nine $(89 \%)$ patients tested (Tourneur et al., 2004). Another study showed expression of Fas on $62 \%$ of 29 AML patients (Min et al., 2004). Fas mutation was observed in 4/28 CML cases and none of the six AML cases tested (Rozenfeld-Granot et al., 2001). DR4 and DR5 mutations detected in cancers including chronic myelogenous leukemia were very low (0$10.6 \%$ ) (Liu et al., 2005). On the other hand, DR4 and DR5 receptors were positive in 20 $(69 \%)$ and $29(100 \%)$ patients, respectively. This study also showed, relapse-free survival was significantly prolonged in patients with CD95-positive AML cells compared with patients with CD95-negative AML cells $(73 \%$ versus $38 \%$ at 3 years; $p=0.047$ ) using univariate analysis (Min et al., 2004). This was however not supported by another study on 99 AML patients where multivariate analysis showed no correlation with overall survival and disease free survival (Brouwer et al., 2001).

Three ligands (TNF-a, FasL and TRAIL) of the TNF-family and their respective four receptors (TNF-R1, Fas, TRAIL-R1 and TRAIL-R2) are potentially important as anti-cancer therapeutics. The demonstration that TNF-a selectively kills tumor cells but not normal cells, set it up for the first molecules to be studied. Unfortunately, marked pro-inflammatory effects precluded its systemic administration (Buzzoni and Butler, 1996). Fas was also excluded as agonistic antibodies triggering Fas activation was highly hepatotoxic causing death in mouse models (Ogasarawa et al., 1993). In contrast, TRAIL and agonistic anti- 
TRAIL-R1/TRAIL-R2 antibodies appear to be well tolerated in vivo. TRAIL/Apo-2L exhibited potent anti-tumor activity and induces little cytotoxic effects in immunodeficient mice xenograft models implanted with several human tumor cell lines (Ashkenazi et al., 1999). However, the in vivo half-life of the TRAIL-ligand is very short ( $<4$ minutes) (Kelley et al., 2001). Agonistic TRAIL-R1 and TRAIL-R2 antibodies do not bind to TRAIL decoy receptors, TRAIL-R3 and TRAIL-R4, which are frequently expressed on the membrane of tumor cells.

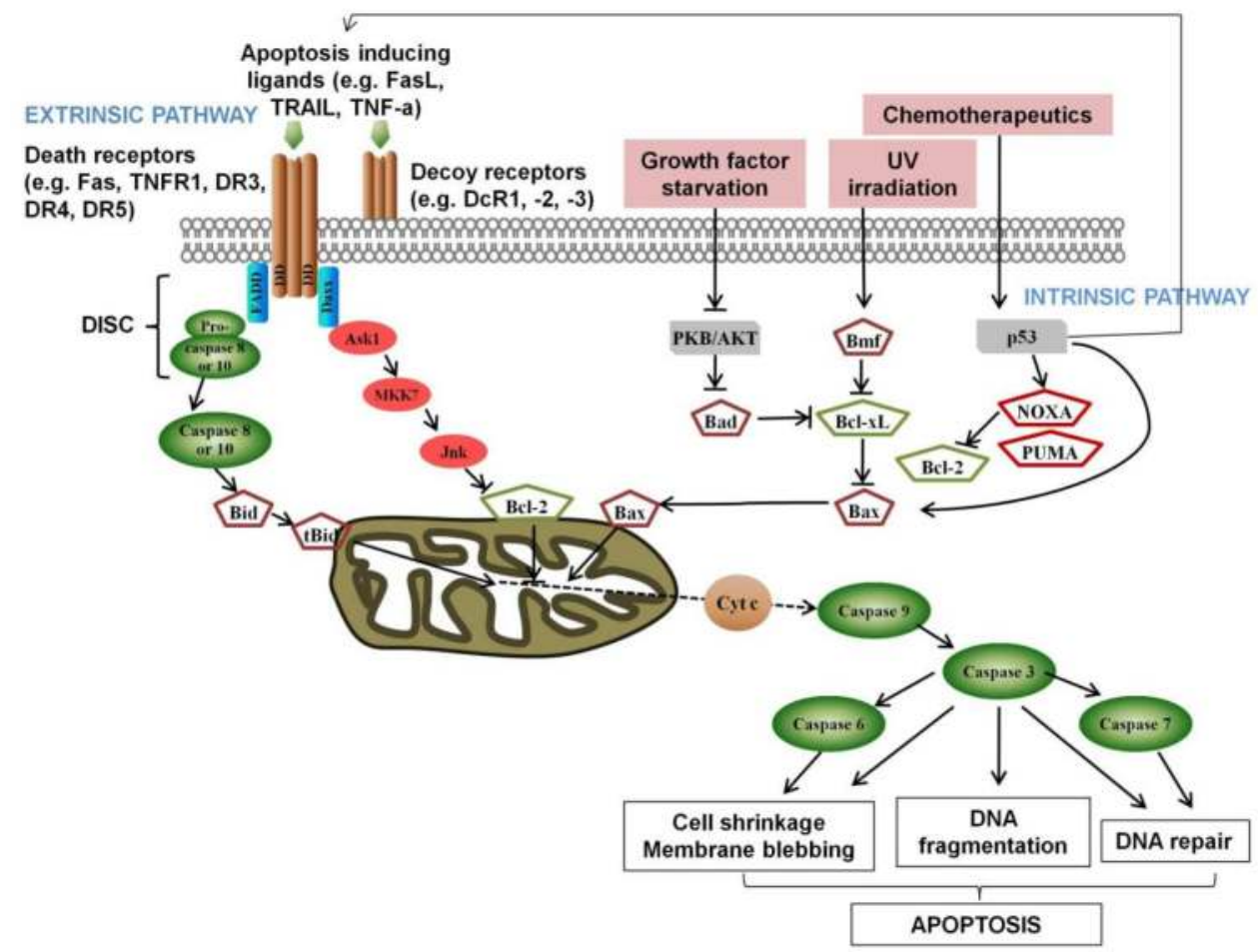

Fig. 1. Extrinsic and intrinsic pathways in apoptosis (see text for further details).

Antisense therapies involved the use of sequences of single-stranded DNA to complement and bind specific coding regions on mRNA hence forming DNA-mRNA which is then degraded by a ribonuclease, therefore gene expression and translation are prevented. Most widely studied were with XIAP (X-linked inhibitor of apoptosis) and antiapoptotic proteins Bcl-2.

Sufficient evidence exists to show that Bcl-2 was overexpressed in AML patients and predictive of worst outcome (Campos et al., 1993; Andreef and Konopleva, 2002). It seemed conceivable that Bcl-2 downregulation might lower the apoptotic threshold of leukemic cells and, through this mechanism, favor response to chemotherapy. Much success has been achieved. A phase I study using oblimersen, an antisense to Bcl-2, added during induction and then consolidation therapy, in elderly AML patients, induced remission in $14 / 27$ patients, of which seven relapsed within 12.6 months (Marcucci et al., 2005); In a multicenter phase II trial, 12/39 relapsed AML patients treated with oblimersen and gentuzamab (anti- 
CD33) achieved complete remission of which 10/12 survived for more than 6 months (Moore et al., 2004).

XIAP binds and inhibits caspases 3, 7, and 9, mediators of the apoptotic cascade. Downregulation of XIAP using multiple approaches (e.g., antisense, RNAi, knock-out animals and cell lines, immuno-depletion) in vitro and in vivo conditions resulted in increased caspase activation and/or cell death. Antitumor activity was also observed with the use of second generation anti-sense compound, AEG35156, in xenograft models of cancer (Lacasse et al., 2005) Results from clinical trials however, have been variable. While one study on five phase 1 (12-350mg/m2 AEG35156) and eight phase $2(350 \mathrm{mg} / \mathrm{m} 2$ AEG35156) patients showed increased apoptotic cells and increase response (Bing et al., 2011) another study on 27 patients randomized to receive high dose Ara-C and idarubicin with or without AEG35156 (650 mg) found a lower overall response rate in the group which received the anti-XIAP drug (Schimmer et al., 2011).

The analysis of Mcl-1 protein expression in AML showed great heterogeneity, but the levels of the protein do not seem to correlate with response to standard chemotherapy (Kaufmann et al., 1998). Bad and Bcl-xL have been shown to be expressed in normal and leukemic hematopoietic precursor cells. Immature hematopoietic cells do not express Bcl-2 but do express Bcl-xL. CD34 positive cells express Bcl-2, Bcl-xL and Bad. Bcl-2 expression is higher on CD34 positive cells than on AML cells. Phosphorylated Bad was expressed in AML (Andreef et al., 1999).

Potential abnormalities of the various initiator caspases in AML have been explored. Levels of caspase-8, caspase-2 and caspase-3 are heterogeneous in AML. AML with an immature phenotype (i.e., M0 and M1 AML) predominantly express caspase-8L (Mohr et al., 2005).The significance of caspases as prognostic indicators in AML are unclear as current reports are still controversial may be due to the different format of molecules examined (Svingen et al., 2000; Estrov et al., 1998; Holleman et al., 2005).

Expression of pro- and anti-apoptotic molecules continues to be studied in AML to correlate its mutated state, expression, activity or methylated state with treatment outcome (Testa et al., 2007). At present, the prognostic utility of measurements of pro- and antiapoptotic molecules for predicting clinical outcome and response to chemotherapy is uncertain.

\section{Drug modulation of signaling, differentiation and apoptotic pathways}

The study of cancer cell biology in predicting treatment outcome cannot stop at the presentation stage as cells continue to be modified by the microenvironment and are ultimately subjected to chemotherapy. While remarkable progress have been achieved in targeted therapies, for most tumors chemo- or radiotherapy is likely to remain in the near future. Both chemo- and radiotherapy are designed to kill cancer cells by damaging nuclear DNA. DNA damage triggers the DNA damage response (DDR) which have three critical goals: (i) halting cell cycle progression and division to prevent transfer of DNA damage to progeny cells; (ii) increasing accessibility of the damage sites to- and engagement of- the DNA damage repair machinery, and (iii) triggering apoptosis to exterminate cells whose damaged DNA cannot successfully be repaired (reviewed in Darzynkiewicz et al., 2009).

Chemotherapeutic drugs such as cisplatin, mitomycin, methotrexate, mitoxantrone, adriamycin, and bleomycin induce Fas expression in human cancer cells, primarily through a p53-dependent mechanism (Muller et al., 1998). Adriamycin, etoposide, Ara-C, cisplatin and camptosar were shown to induce the expression of DR4 and DR5 or only DR5 
expression, through either p53-dependent, or p53-independent mechanisms (Wu et al., 1997; Guan et al., 2001; Sheikh et al., 1998). Etoposide was shown to induce DR5 expression in human acute leukemia cells (Wen et al., 2000).

To complete induction of cell death, chemotherapeutic drugs have to suppress survival mediators in activated signaling pathways. Paclitaxel treatment of transfected MDA MB-435 human breast carcinoma cell line was observed to downregulate phosphorylated Akt (Klos et al., 2003). Nevertheless, chemotherapy induction of cell death is not equal in all cells. Adriamycin produced differential responses in Akt phosphorylation and kinase activity in a panel of breast cancer cell lines. While MCF7, MDA468 and T47D cells showed a dose dependent increase in p-Akt levels; in contrast, SKBR3 and MDA231 cells showed a dosedependent decrease and no or minimal change was detected in MDA361, MDA157 and BT474 cells ( $\mathrm{Li}$ et al., 2005). The diversity in response may also be predictive of a heterogeneity in treatment outcome.

Other signaling molecules are activated by chemotherapeutic drugs leading to cell death. Ara-C induced apoptosis in HL-60 cell lines through the activation of p38 (Stadheim et al., 2000). Adriamycin was shown to activate Jnk in a T cell leukemia cell line (Yu et al., 1999). Leukemia cell lines (TF-1 and K562) primed for apoptosis were also revealed to stimulate Jnk and p38 phosphorylation (Tucker et al., 2004)

Certain cytokines have apoptotic activity. TNF-alpha and IFN-gamma induced the expression of DR5 in a number of cancer cell lines (Meng and El-Deiry, 2000). IFN-gamma had differential effect on induction of death receptors in colon carcinoma cell lines. While it raised the levels of CD95 membrane 6 - 8-fold, it had no effect on the TRAIL-receptors (DR4, DR5, DcR1 and DcR2) (van Geelan et al., 2003). Interferon-alpha was also reported to increase DR5 expression in human hepatoma (Shigeno et al., 2003).

In contrast some cytokines exert protective effect from chemotherapeutic drug induced cell death, decreasing the effectiveness of cancer radiotherapy and chemotherapy. Normal hematopoietic cells, like other normal cell types, die by the process of apoptosis when deprived of viability inducing cytokines that include colony stimulating factors (CSFs) and various other cytokines. Induction of apoptosis by cancer chemotherapy such as vincristine, adriamycin, methotrexate and Ara-C was suppressed by IL (interleukin)-6, IL-3, granulocyte-CSF (G-CSF), granulocyte-monocyte CSF (GM-CSF) and IFN-gamma in myeloid leukemia cells (reviewed in Lotem and Sachs, 2002). These cytokines upregulate pro-survival molecules such as Bcl-2 [IL-2, IL-3, stem cell factor (SCF), IFN-gamma], Bcl-xL [IL-3, IL-6, IL-7, IL15, GM-CSF, IFN-gamma and erythropoietin (EPO)] and other apoptosis suppressing genes such as Survivin (Carter et al., 2001), X-linked inhibitor of apoptosis protein (XIAP) and cellular inhibitor of apoptosis 2 (cIAP2) (Digicylioglu and Lipton, 2001) that are caspase inhibitors and FLICE-like inhibitory protein (FLIP), that may disrupt the ability of cell surface molecules such as Fas to activate apoptosis (Kovalovich et al., 2001) Some myeloid leukemic cells are autonomous and do not require an exogenous source of cytokines for viability (Griffin and Lowenberg,1986), while others do. Thus, it is possible to suppress leukemia not only by cytotoxic agents or by induction of terminal differentiation, but also by decreasing the in vivo supply of apoptosis suppressing cytokines or the response of leukemic cells to these cytokines (reviewed in Sachs, 1996).

A characteristic abnormality of leukemia cells is that they are blocked at an early stage of their development. Myeloid leukemic cells however can be induced to differentiate to non dividing mature granulocytes and macrophages by different cytokines, including cytokine 
independent myeloid leukemic cells that were induced to differentiate with IL-6. Different myeloid leukemic clones however have different blocks and ability to undergo differentiation by cytokines. Our own work on in vitro cultured AML blasts exhibited different degrees of spontaneous apoptosis. Univariate analysis of 13 AML patients revealed blasts with lower levels of cell viability after $72 \mathrm{~h}$ culture was significantly correlated with a longer disease free survival. Within a smaller number of samples $(n=7)$ we observed blasts with lower levels of cell viability were associated with reduced levels CD34 and higher levels of CD16, indicating an increased level of cell differentiation (Maha et al., 2008). The observations may indicate an abnormal developmental program in leukemic cells which may be reprogrammed epigenetically by appropriate differentiation inducing cytokines. Constitutive expression of transcription factors such as c-myc, c-myb and E2F1 (Gonda and Metcalf, 1984; Blatt et al., 1992; Melamed et al., 1993) as well as others such as the homeobox gene Hox B8 (Hox 2.4) (Blatt et al., 1992) or GATA-1 (Tanaka et al., 2000), disrupted the ability of cells to undergo cytokine induced differentiation (reviewed in Lotem and Sachs, 2002)

Cytokines as a differentiation treatment against leukemia however has been disappointing. Hematopoietic leukemia cell lines of myeloid origin such as K562, U937, HL-60, CS-1, KG-1, MUTZ-3, or ex vivo AML or chronic myeloid leukemia (CML) blasts were modestly permissive to induction of in vitro differentiation by EPO, G-CSF, GM-CSF, IL-4, IL-6, SCF, or synergistic combinations of several cytokines (Leung et al., 2005; Koss et al., 1996; Goliaei et al. 1998; Kamano et al., 1994; Kamijo et al., 1990). A niche for hematopoietic cytokines in differentiation therapy exists in the treatment of congenital neutropenia disorder. The administration of G-CSF to patients has overcome a block of myeloid differentiation leading to a substantial prolongation of their survival (Berliner, 2008).

Clinically, differentiation therapy has been most successful in acute promyelocytic leukemia (APL) using all-trans-retinoic acid (ATRA) as the inducer. This targeted APL cells carrying the chromosomal translocation between chromosomes 15 and 17 [t(15;17)(q22;q21)]. Subsequently, APL therapy was improved with the combination regimen of ATRA with cytotoxic chemotherapy. Currently, complete remission rates of up to $90 \%$ to $95 \%$ are achievable using ATRA/ATO (arsenic trioxide) and anthracycline-based chemotherapy (Niu et al., 1999; Soignet et al., 2001; Raffoux et al., 2003; Ghavamzadeh et al., 2006; Mathews et al., 2006; Estey et al., 2006; Sanz et al., 2008).

Another targeted treatment with tyrosine kinase inhibitor (TKI) imatinib for the treatment of CMLalso achieved better success. Gefinitib and erlotinib which inhibit the intracellular tyrosine kinase activity of epidermal growth factor receptor (EGFR), induce a differentiation program in myeloid leukemia cells that corresponds to neutrophil maturation (Stegmaier et al., 2005; Boehrer et al., 2008a; Boehrer et al., 2008b).

These results together emphasize further not only the heterogeneity of leukemias but also complexity of host-cancer interaction and its influence on outcome in survival and also during induction of cell death.

\section{In vivo drug induced molecular profiles: Potential predictor of drug resistance}

The in vivo molecular changes in acute myeloid leukemia cells early after start of conventional genotoxic chemotherapy are incompletely understood, and it is not known if early molecular modulations reflect clinical response. As increasing evidence is proposing 
tumor-host mechanisms as important for effective chemotherapy, there is an immediate need to investigate these issues in vivo in human cancer (Oyan et al., 2009)

For that purpose, blasts from patients undergoing chemotherapy were collected as a 'natural' and rich source to study response of these cells to the myriad of signals they were subjected to. Even though cells undergo cell death, as white blood cell counts may decline at early stages of chemotherapy, very low percentages of apoptotic cells were detected. Oyan et al. (2009) comparing treated (' $3+7$ ', idarubicin + Ara-C ) with untreated AML cells from seven patients, observed upregulation of 113 genes (23 of unknown function) at early time points ( $2-4$ hours) and 108 genes at late time points (18 - 24 hours). Among the 113 genes a substantial number (31 genes) were related to the tumor suppressor p53 (Oyan et al., 2009). p53 is implicated to affect a variety of cellular processes, the most undisputed roles of p53 are to induce growth arrest and to induce apoptosis (Bates and Vousden, 1996). p53 is the most commonly mutated gene in a variety of human cancers (Greenblatt et al., 1994). In AML however, mutations of p53 are rare, occurring in approximately $5 \%$ to $10 \%$ (Fenaux et al., 1992) but in these cases it correlates with worse outcome (Wattel et al., 1994). Wild-type p53 appears to change the balance in expression of apoptosis-inducing versus apoptosissuppressing genes in favor of the former and thus induce apoptosis.

In tune with the above, a significant increase in gene expression of the apoptosis facilitators PUMA and Bax and a decrease in the Bcl-2 / Bax ratio as well as Bcl-2 /PUMA were observed for most of the AML samples. The mRNA profile of three other pro-apoptotic mediators Bad, Bak1 and Bim did not change significantly during the first hours, but the level of gene expression varied across patients. Altogether five tumor necrosis factor-related receptor genes were modulated 2-4 h after induction therapy (Oyan et al., 2009).

Induction of ligand to death receptor during chemotherapy was also supported by Devemy et al. (2001) who observed increased TNF transcripts in treated AML cells. We also studied molecular changes in paired AML samples at diagnosis and during chemotherapy ( Ara-C + daunorubicin). We showed increased TNF-alpha was significantly higher in chemo-sensitive patients. Thus, expression of TNF-alpha early during chemotherapy may be a marker to predict good treatment outcome. In chemo-resistant cases, a higher, though not significant, percentage of cases expressed IL-1beta and IL-18 (Maha et al., 2009).

We observed a significantly higher percentage of chemo-responsive AML patients with blasts cells increased for the expression of IL-6. This was consistent with Devemy et al (2001) who reported that increase of IL-6 transcripts during remission induction therapy of AML patients was accompanied by a fall in blood count and bone marrow cellularity. The role of cytokines in the induction of cell differentiation is well established. Oyan et al (2009) also observed several receptors expressed on monocytic/macrophage lineage cells were upregulated, probably related to chemotherapy induced differentiation of the leukemic cells. Thus, induction of cytokines expression in drug responsive AML patients may be due to induction of cell differentiation.

Comparing blasts profiles before and during early chemotherapy also revealed upregulation of genes potentially involved in interaction between AML blasts and the host microenvironment. Chemokine receptors CXCR4 and CX3CR1 were upregulated in the late phase after start of chemotherapy indicating intention to home into a microenvironment that favours their growth and survival. This supports the hypothesis that the host response in chemotherapy is crucial for persistent remission (Oyan et al., 2009). 
We further examined activation of signaling molecules in AML blasts. Chemotherapy increased the percentage of cases showing phosphorylation of the Akt molecules and Forkhead transcription factor (FKHR) but no significant differences were observed between chemo-resistant and chemo-sensitive cases. We however, observed a significantly higher percentage of chemo-resistant cases showing phosphorylation and inactivation of the proapoptotic Bad molecule. A higher percentage of chemo-sensitive cases were phosphorylated for p38, and Jnk (Maha et al., 2009). In summary, we were able to show in chemo-sensitive cases, chemotherapy stimulated IL-6, induced apoptosis by up-regulating TNF-alpha and downregulated phosphorylated Bad. In reverse, in chemo-resistant cases, cells survived by maintaining high levels of phosphorylated Bad maybe through protective role of IL-1b and IL-18 cytokines (Maha et al., 2009).

Most anticancer drugs exert their effects by the induction of apoptosis and/or interfering with cell cycle progression. Often these drugs give rise to specific patterns of cell death and cell cycle arrest that vary according to the drug used and the molecular status of the target cell. Simple in vitro methods may aid in this investigation. Drug cytotoxicity and sensitivity of individual tumor samples was demonstrated by combining cytochrome $\mathrm{c}$ and propidium iodide staining of DNA content and detected on flowcytometry. This method elucidated mitochondrial resistance mechanisms which may prove useful in identifying the apoptosissensitive cell cycle phase for a given tumor sample/anticancer drug combination. It offers the opportunity to design personalized drug regimens and to identify new combined treatment modalities (Mohr et al., 2004).

\section{Conclusion}

The heterogeneity in AML continues to elude the best methods to characterize them. Genome and proteome-wide analysis has further revealed complexity in the makeup of the leukemic cell. The rapid advancement in targeted therapies implied the urgent need for alternative therapy and the readiness of the community to embrace it. Nevertheless so far, combinatorial medicine still holds out as the best option for successful treatment. If targeted therapies remain the way forward it will eventually bank deeply on the ability to identify molecular signatures in the individual leading to the establishment of personalized medicine.

In the meantime, the mechanisms in leukemogenesis, drug resistance and relapse remain an area of much research. From cell biology to cytogenetics to molecular defects to signaling pathways, all have contributed to a better understanding of cancer biology. New knowledge in epigenetics and microRNA remain to be elucidated.

Current diagnostic and prognostication are based on the assumption that the phenotype of the leukemic cell is static and thus definitive. There is much evidence that suggest otherwise. Activation of oncogenes leads to constitutive expression of signal transduction pathways involved in cell survival and anti-apoptotic activities. These pathways are multiple and made up of a myriad of molecules that are receptive to the environment. The host-cancer microenvironment is a dynamic microcosm of interacting signals and cascading molecules that constantly respond to stimuli in the surrounding to find a balance that maintains survival. In the course of treatment, blast cells are exposed to DNA damaging cytotoxic agents which trigger a gamut of other signaling mediators to exert the opposite effect. It would appear that a struggle ensues in which the strength of the victor determines whether the blast cell would maintain life or be pushed off-balance and replaced with a new 
profile signaling cell death. This new phenotype corresponded to a sensitive response to chemotherapy. On the other hand, cells may strengthen on pro-survival features which corresponded with resistance to chemotherapy. A few reports, including ours, are lending support to this hypothesis.

Unsurprisingly, chemotherapy-induce phenotype is not confined purely to either a survival or an apoptosis profile but a complex mix of conflicting signals to survive or die in addition to triggers to shut down cell proliferation, induce terminal differentiation or activate inflammatory responses. Thus, further elucidation of these profiles would involve assignment of each of the modulated molecule to its rightful pathway.

The immaturity feature in leukemias will undoubtedly be a factor that will further compound the heterogeneity in results obtained. An example is the striking correlations found between lower Bax/Bcl-2 ratio and higher progenitor marker expression, such as CD34, CD117 and CD133 antigens, confirming the link between this apoptotic index and the maturation pathways (Del Principe et al., 2005). Attempts to induce cell death by triggering death receptors has so far achieved mix results with the use of TNF-alpha, Fas ligands and the tumor necrosis factor-related apoptosis-inducing ligand (TRAIL) (i.e., DR4 and DR5). These molecules also selectively kill cancer cells while sparing normal cells (reviewed in Elrod and Sun, 2008). These results indicate a preferential expression of specific death receptors on different tissues.

Selection of lab methods for prognostication depends on the ability to identify lineage, maturation stages, genetic aberrations and activated signal transduction pathways. This feat may include the difficult task of combining surface markers, cytokines (secreted proteins) and phosphorylated proteins (unstable intracellular proteins) in the same tube on the same platform such as flowcytometry. Furthermore many of these proteins such as TNF-a, IL-6, p38 and Jnk have dual function of pro-survival and pro-apoptosis capabilities depending on the stimulating conditions cells are exposed to at that period of time. Precise markers will be required to differentiate these situations. Altogether, all of these add up to an interesting and exciting field of research for the immediate future.

\section{References}

[1] American Cancer Society. Cancer facts \& figures 2010. American Cancer Society Web site. http:/ / www.cancer.org. Accessed June 29, 2010.

[2] Andreeff M, Jiang S, Zhang X, Konopleva M, Estrov Z, Snell VE et al. Expression of Bcl-2 related genes in normal and AML progenitors: changes induced by chemotherapy and retinoic acid. Leukemia 1999; 11: 1881-1892.

[3] Andreef M, Konopleva M. Mechanisms of drug resistance in AML. Cancer Treat Res 2002;112: 237-262.

[4] Ashkenazi A, Herbst RS. To kill a tumor cell: the potential of proapoptotic receptor agonists. J Clin Invest. 2008 Jun;118(6):1979-1990.

[5] Ashkenazi A, Pai RC, Fong S, Leung S, Lawrence DA, Marsters SA, et al. Safety and antitumor activity of recombinant soluble Apo2 ligand. J Clin Invest 1999;104:155162.

[6] Bates, S., and Vousden, K. H. p53 in signaling checkpoint arrest or apoptosis. Curr. Opin. Genet. Dev. 1996; 6: 1-7.

[7] Bazzoni F, Butler B. The tumor necrosis factor ligand and receptor families N Engl J Med 1996;334: 1717-1725. 
[8] Berliner N. Lessons from congenital neutropenia: 50 years of progress in understanding myelopoiesis. Blood. 2008;111:5427-5432.

[9] Bing ZC, Duncan HM, Stephen JM, et al. XIAP antisense oligonucleotide (AEG35156) achieves target knockdown and induces apoptosis preferentially in CD34+38 cells in a phase 1/2 study of patients with relapsed/refractory AML. Apoptosis;2011: 16:67-74.

[10] Blatt C, Lotem J and Sachs L. Inhibition of specific pathways of myeloid cell differentiation by an activated Hox-2.4 homeobox gene. Cell Growth Differ. 1992; 3, 671-676.

[11] Boehrer S, Ades L, Galluzzi L, et al. Erlotinib and gefitinib for the treatment of myelodysplastic syndrome and acute myeloid leukemia: a preclinical comparison. BiochemPharmacol. 2008a;76:1417-1425.

[12] Boehrer S, Ades L, Braun T, et al. Erlotinib exhibits antineoplastic off-target effects in AML and MDS: a preclinical study. Blood. 2008b;111:2170-2180.

[13] Byrd JC, Mrozek K, Dodge RK, et al. Pretreatment cytogenetic abnormalities are predictive of induction success, cumulative incidence of relapse, and overall survival in adult patients with de novo acute myeloid leukemia: results from Cancer and Leukemia Group B (CALGB 8461). Blood. 2002;100:4325-4336.

[14] Campos L, Rouault JP, Sabido O. High expression of bcl-2 protein in acute myeloid leukemia cells is associated with poor response to chemotherapy. Blood 1993;81: 3091-3096.

[15] Carter BZ, Miella M, Altieri DC and Andreef M. Cytokine-regulated expression of survivin in myeloid leukemia. Blood. 2001; 97, 2784-2790.

[16] Castaigne S, Chevret S, Archimbaud E, et al. Randomized comparison of double induction and timed-sequential induction to a "37" induction in adults with AML: long-term analysis of the Acute Leukemia French Association (ALFA) 9000 study. Blood. 2004;104:2467-2474.

[17] Cheson B, Bennett J, Kopecky K et al. Revised recommendations of the International Working Group for diagnosis, standardization of response criteria, treatment outcomes, and reporting standards for therapeutic trials in acute myeloid leukemia, J ClinOncol. 2003;21:4642-4649.

[18] Cornelissen JJ, van Putten WL, Verdonck LF, et al. Results of a HOVON/SAKK donor versus no-donor analysis of myeloablative HLA-identical sibling stem cell transplantation in first remission acute myeloid leukemia in young and middleaged adults: benefits for whom? Blood. 2007;109:3658 -3666.

[19] Damiani D, Tiribelli M, Michelutti A et al. Fludarabine-based induction therapy does not overcome the negative effect of ABCG2 (BCRP) over-expression in adult acute myeloid leukemia patients. Leuk Res. 2010;34(7):942-945.

[20] Daniela D, Mario T, Donatella R et al. The role of MDR-related proteins in the prognosis of adult acute myeloid leukaemia (AML) with normal karyotype. HematolOncol 2007; 25: 38-43.

[21] Darzynkiewicz Z, Traganos F, Wlodkowic D. Impaired DNA damage response--an Achilles' heel sensitizing cancer to chemotherapy and radiotherapy. Eur J Pharmacol. 2009;625(1-3):143-150. 
[22] Del Principe MI, Del Poeta G, Venditti A, Buccisano F, Maurillo L, Mazzone C, Bruno A, Neri B, IrnoConsalvo M, Lo Coco F,Amadori S. Apoptosis and immaturity in acute myeloid leukemia. Hematology. 2005;10(1):25-34.

[23] Devemy E, Li B, Tao M et al. Poor prognosis acute myelogenousleukemia: 3-biological and molecular biological changes during remission induction therapy. Leuk Res 2001; 25(9):783-791.

[24] Digicaylioglu M and Lipton SA. Erythropoietin-mediated neuroprotection involves cross-talk between Jak2 and NF-kappaBsignalling cascades. Nature. 2001; 412, 641 647.

[25] Dohner H, Estey EH, Amadori S, et al. Diagnosis and management of acute myeloid leukemia in adults: recommendations from an international expert panel, on behalf of the European LeukemiaNet. Blood. 2010;115:453- 474

[26] Dufour A, Schneider F, Metzeler KH, et al. Acute myeloid leukemia with biallelic CEBPA gene mutations and normal karyotype represents a distinct genetic entity associated with a favorable clinical outcome. J ClinOncol. 2010;28:570 -577.

[27] Eric S, Bernard D, Lydia C et al. Quinine as a multidrug resistance inhibitor: a phase 3 multicentric randomized study in adult de novo acute myelogenousleukemia. Blood.2003;102:1202-1210.

[28] Estey E, Kornblau S, Pierce S et al. A stratification system for evaluating and selecting therapies in patients with relapsed or primary refractory acute myeloid leukaemia. Blood 1996;88:756.

[29] Estey E, Garcia-Manero G, Ferrajoli A, et al. Use of all-trans retinoic acid plus arsenic trioxide as an alternative to chemotherapy in untreated acute promyelocyticleukemia. Blood. 2006;107:3469-3473.

[30] Estrov Z, Thall PF, Talpaz M, Estey EH, Kantarjian HM, Harris D, et al. Caspase 2 and caspase 3 protein levels as predictors of survival in acute myelogenousleukaemia.Blood 1998; 92:3090-3097.

[31] Falini B, Mecucci C, Tiacci E, et al. Cytoplasmic nucleophosmin in acute myelogenousleukemia with a normal karyotype. N Engl J Med. 2005;352:254 -266.

[32] Fenaux P, Preudhomme C, Quiquandon I, et al. Mutations of the p53 gene in acute myeloid leukaemia. Br J Haematol. 1992;80:178-183.

[33] Frederick R A, Holly G, David R H, et al. Age and acute myeloid leukemia. Blood. 2006 107: 3481-3485.

[34] Futscher BW, Foley NE, Gleason-Guzman MC, Meltzer PS, Sullivan DM, Dalton WS. Verapamil suppresses the emergence of P-glycoproteinmediated multi-drug resistance. Int J Cancer. 1996;66:520-525.

[35] Ghavamzadeh A, Alimoghaddam K, Ghaffari SH, et al. Treatment of acute promyelocyticleukemia with arsenic trioxide without ATRA and/or chemotherapy. Ann Oncol. 2006;17:131-134.

[36] Gibson BE, Wheatley K, Hann IM, et al. Treatment strategy and long-term results in paediatric patients treated in consecutive UK AML trials. Leukemia. 2005;19:21302138.

[37] Goliaei B, Deizadji A. Effects of hyperthermia and granulocyte-macrophage colonystimulating factor on the differentiation of human leukemic cell line U937. Leuk Res. 1998;22:705-710. 
[38] Gonda TJ and Metcalf D. Expression of myb, myc and fos proto-oncogenes during the differentiation of a murine myeloid leukaemia. Nature. 1984; 310, 249- 251.

[39] Greenblatt, M. S., Benneu, W. P., Hollstein, M., and Harris, C. C. Mutations in the p53 tumorsuppressorgene: clues to cancer etiology and molecular pathogenesis. Cancer Res. 1994; 54: 4855-4878.

[40] Griffin JD and Lowenberg B. (1986).Clonogenic cells in acute myeloblastic leukemia. Blood. 1986; 68, 1185-1195

[41] Grimwade D. Impact of cytogenetics on clinical outcome in AML. In: Karp JE, ed. Acute MyelogenousLeukemia. Totowa, New Jersey: Humana Press; 2007:177-192.

[42] Grimwade D, Hills RK. Independent prognostic factors for AML outcome.Hematology Am SocHematolEduc Program. 2009:385-395.

[43] Grimwade D, Hills RK, Moorman AV, et al. Refinement of cytogenetic classification in acute myeloid leukemia: determination of prognostic significance of rare recurring chromosomal abnormalities amongst 5,876 younger adult patients treated in the UK Medical Research Council trials. Blood. 2010;116:354-365.

[44] Guan B, Yue P, Clayman GL, Sun SY. Evidence that the death receptor DR4 is a DNA damage-inducible, p53-regulated gene. J Cell Physiol 2001; 188:98-105.

[45] Holleman A, Den Boer M, Kazemeier KM, Beverloo HB, Von Bergh A, Janka-Schaub GE, et al. Decreased PARP and procaspase-2 protein levels are associated with cellular drug resistance in childhood lymphoblastic leukemia. Blood 2005;106:18171823.

[46] Huh HJ, Park CJ, Jang S et al. Prognostic significance of multidrug resistance gene 1 (MDR1), multidrug resistance-related protein (MRP) and lung resistance protein (LRP) mRNA expression in acute leukemia. J Korean Med Sci. 2006 Apr;21(2):253258.

[47] Izquierdo M, Scheffer G, Flens M et al. Major vault protein LRP-related multidrug resistance. Eur J Cancer. 1996;32A:979-984.

[48] Jean-Pierre M, Ollivier L. Drug resistance in acute leukaemia and reversion. Turk J Med Sci. 2003;33:271-279.

[49] Jonathan EK, Stephen LG, Guido M et al. P-glycoprotein inhibition using valspodar (PSC-833) does not improve outcomes for patients younger than age 60 years with newly diagnosed acute myeloid leukemia: Cancer and Leukemia Group B study 19808. Blood 2010 116: 1413-1421.

[50] Kamano H, Tanaka T, Ohnishi H, et al. Effects of the antisense myb expression on hemin- and erythropoietin-induced erythroid differentiation of K562 cells. BiochemMolBiol Int. 1994;34:85-92

[51] Kamijo R, Takeda K, Nagumo M, Konno K. Effects of combinations of transforming growth factor-beta 1 and tumor necrosis factor on induction of differentiation of human myelogenous leukemic cell lines. J Immunol. 1990;144:1311-1316.

[52] Kaufmann SH, Karp JE, Svingen PA, Kraiewski S, Burke PJ, Gore SD, Reed JC. Elevated expression of the apoptotic regulator Mcl-1 at the time of leukemic relapse. Blood 1998;91: 991-1000.

[53] Kelley S, Harris L, Xie D, DeForge L, Totpal K, Bussiere J, et al. Preclinical studies to predict the disposition of Apo2L/tumor necrosis factor-related apoptosis-inducing ligand in humans: characterization on in vivo efficacy, pharmacokinetics, and safety. J PharmacolExpTher 2001;299: 31-38. 
[54] Klos KS, Zhou X, Lee S, Zhang L, Yang W, Nagata Y, Yu D. Combined trastuzumab and paclitaxel treatment better inhibits ErbB-2-mediated angiogenesis in breast carcinoma through a more effective inhibition of Akt than either treatment alone. Cancer. 2003;98(7):1377-1385.

[55] Koreth J, Schlenk R, Kopecky KJ, Honda S, Sierra J, Djulbegovic BJ, Wadleigh M, DeAngelo DJ, Stone RM, Sakamaki H, Appelbaum FR, Döhner H, Antin JH, Soiffer RJ, Cutler C. Allogeneic stem cell transplantation for acute myeloid leukemia in first complete remission: systematic review and meta-analysis of prospective clinical trials. JAMA. 2009;301(22):2349-2361.

[56] Koss A, Lucero G, Koziner B. Granulocyte-colony stimulating factor, granulocytemacrophage colony stimulating factor and interleukin 4 induce differentiation in the U-937 human monocyticleukemia cell line. Leuk Lymphoma. 1996;22:163171. follow. 186, color plate XIV-V.

[57] Kovalovich K, Li W, DeAngelis R, Greenbaum LE, Ciliberto G and Taub R. Interleukin6 protects against Fas-mediated death by establishing a critical level of antiapoptotic hepatic proteins FLIP, Bcl-2, and Bcl-xLJ. Biol. Chem. 2001; 276, 2660526613.

[58] Krauter J, Wagner K, Schäfer I, Marschalek R, Meyer C, Heil G, Schaich M, EhningerG,Niederwieser D, Krahl R, Büchner T, Sauerland C, Schlegelberger B, Döhner K, DöhnerH,Schlenk RF, Ganser A. Prognostic factors in adult patients up to 60 years old with acute myeloid leukemia and translocations of chromosome band11q23: individual patient data-based meta-analysis of the German Acute Myeloid Leukemia Intergroup. J ClinOncol. 2009; 27(18):3000-3006.

[59] Lacasse EC, Kandimalla ER, Winocour P, et al. Application of XIAP antisense to cancer and other proliferative disorders: development of AEG35156/ GEM640. Ann N Y Acad Sci. 2005;1058:215-234.

[60] Lamba JK, Crews KR, Pounds SB, Cao X, Gandhi V, Plunkett W, Razzouk BI, Lamba V, Baker SD, Raimondi SC, Campana D, Pui CH, Downing JR, Rubnitz JE, Ribeiro RC. Identification of predictive markers of cytarabine response in AML by integrative analysis of gene-expression profiles with multiple phenotypes. Pharmacogenomics. 2011;12(3):327-339.

[61] Leith CP, Kopecky KJ, Chen IM, Eijdems L, Slovak ML, McConnell TS, Head DR, Weick J, Grever MR,Appelbaum FR, Willman CL. Frequency and clinical significance of the expression of the multidrug resistance proteins MDR1/P-glycoprotein, MRP1, and LRP in acute myeloid leukemia: a Southwest Oncology Group Study. Blood. 1999;94(3):1086-99.

[62] Leung KN, Mak NK, Fung MC. Cytokines in the differentiation therapy of leukemia: from laboratory investigations to clinical applications.Crit Rev Clin Lab Sci. 2005;42(5-6):473-514.

[63] Li X, Lu Y, Liang K, Liu B, Fan Z. Differential responses to doxorubicininduced phosphorylationand activation of Akt in human breast cancer cells. Breast Cancer Res. 2005;7(5):R589-597.

[64] Liu YJ, Wheatley K, Rees J et al. Comparison of two chemotherapy regimen with or without cyclosporine A in relapse/refractory acute myeloid leukaemia: result of the UK Medical Research Council AML-R Trial. Blood 1998;92:231a. 
[65] Liu LG, Tanaka H, Ito K, Ito T, Sultana TA, Kyo T, Kimura A. Absence of gene mutation in TRAIL receptor 1 (TRAIL-R1) and TRAIL receptor 2 (TRAIL-R2) in chronic myelogenousleukemia and myelodysplastic syndrome, and analysis of mRNA Expressions of TRAIL and TRAIL-related genes in chronic myelogenousleukemia. ActaHaematol 2005; 113:113-123.

[66] Lowenberg, B., Ossenkoppele, G.J., van Putten, W.,etal.High dose daunorubicin in older patients with acute myeloid leukemia.NEng J Med. 2010a;361:1235-1248.

[67] Lowenberg B, Beck J, GrauxC,et al. Gemtuzumabozogamicin as postremission treatment in AML at 60 years of age or more: results of a multicenter phase 3 study. Blood. 2010b; 115: 2586-2591.

[68] Maha A, Cheong SK, Leong CF, Seow HF. Cell viability of acute myeloid leukaemia blasts in culture correlates with treatment outcome.Hematology. 2008;13(1):13-20.

[69] Maha A, Cheong SK, Leong CF, Seow HF. Molecular responses during chemotherapy in acute myeloid leukemias in predicting poor-response to standard chemotherapy.Malays J Pathol. 2009 Dec;31(2):81-91.

[70] Marcucci G, Stock W, Dai G, Klisovic RB, Liu S, Klisovic MI, Blum W, Kefauver C, Sher DA, Green M,Moran M, Maharry K, Novick S, Bloomfield CD, Zwiebel JA, Larson RA, Grever MR, Chan KK, Byrd JC. Phase I study of oblimersen sodium, an antisense to $\mathrm{Bcl}-2$, in untreated older patients with acute myeloid leukemia: pharmacokinetics, pharmacodynamics, and clinical activity. J Clin Oncol. 2005 May 20;23(15):3404-11.

[71] Mathews V, George B, Lakshmi KM, et al. Single-agent arsenic trioxide in the treatment of newly diagnosed acute promyelocyticleukemia: durable remissions with minimal toxicity. Blood.2006;107:2627-2632.

[72] Melamed D, Tiefenbrun N, Yarden A and Kimchi A. Interferons and interleukin-6 suppress the DNA-binding activity of E2F in growth-sensitive hematopoietic cells. Mol. Cell. Biol. 1993; 13, 5255-5265.

[73] Meng RD, El-Deiry WS. p53-independent upregulation of KILLER/DR5 TRAIL receptor expression by glucocorticoids and interferon-gamma. Exp Cell Res. 2001;262(2):154-169.

[74] Min YJ, Lee JH, Choi SJ, Chi HS, Lee JS, Kim WK, Lee KH. Prognostic significance of Fas (CD95) and TRAIL receptors (DR4/DR5) expression in acute myelogenousleukemia. Leukemia research 2004; 28:359-365.

[75] Mohr A, Zwacka RM, Debatin KM and Stahnke K. A novel method for the combined flow cytometric analysis of cell cycle and cytochrome c release. Cell Death and Differentiation (2004) 11, 1153-1154.

[76] Mohr A, Zwacka RM, Jarmy G, Buneker C, Schrezenmeier H, Dohner K, et al. Caspase$8 \mathrm{~L}$ expression protects $\mathrm{CD} 34+$ hematopoietic progenitor cells and leukemic cells from CD95-mediated apoptosis. Oncogene 2005; 24:2421-2429.

[77] Moore LO, Seiter K, Kolitz JE, Stock W, Yu R, Frankel SR. Phase 2 study of oblimersen sodium (G31\39; Bcl-2 antisense; Gena sense) plus gentuzumabozogamicin (Myelotarg) in elderly patients with relapsed acute myeloid leukemia (AML). Blood 2004;104:247a.

[78] Motoji T, Motomura S, Wang YH. Multidrug resistance of acute leukemia and a strategy to overcome it. Int J Hematol 2000 Dec;72(4):418-24. 
[79] Mrozek K, Radmachera MD, Bloomfield CD and Marcucci G. Molecular signatures in acute myeloid leukemia. CurrOpinHematol 16:64-69

[80] Muller M, Wilder S, Bannasch D, Israeli D, Lehlbach K, Li-Weber M, Friedman SL, Galle PR, Stremmel W, Oren M, Krammer PH. p53 activates the CD95 (APO-1/Fas) gene in response to DNA damage by anticancer drugs. J Exp Med 1998; 188:20332045.

[81] Nabhan C, Rundhaugen LM, Riley MB, et al. Phase II pilot trial of gemtuzumabozogamicin (GO) as first line therapy in acute myeloid leukemia patients age 65 or older. Leukemia Research.2005;29:53-57

[82] Niu C, Yan H, Yu T, et al. Studies on treatment of acute promyelocyticleukemia with arsenic trioxide: remission induction, follow-up, and molecular monitoring in 11 newly diagnosed and 47 relapsed acute promyelocyticleukemia patients. Blood. 1999;94:3315-3324.

[83] Nowak D, Stewart D, Koeffler HP. Differentiation therapy of leukemia: 3 decades of development. Blood. 2009;113(16):3655-3665.

[84] O'Donnell MR, Appelbaum FR, Coutre SE, et al. Acute myeloid leukemia: NCCN clinical practice guidelines in oncology, v.2.2010. National Comprehensive Cancer Network On-Line. http:/ / wwwnccnorg. Accessed April 18, 2010.

[85] Ogasarawa J, Watanabe-Fukunaga R, Adachi M, Matsuzawa A, Kasugai T, Kita mura Y, et al. Lethal effect of the anti-Fas antibody in the mice. Nature 1993; 364: 806-809.

[86] Øyan AM, Anensen N, Bø TH, Stordrange L, Jonassen I, Bruserud Ø, Kalland KH, Gjertsen BT. Genes of cell-cell interactions, chemotherapy detoxification and apoptosis are induced during chemotherapy of acute myeloid leukemia.BMC Cancer. 2009; 9:77.

[87] Paschka P, Marcucci G, Ruppert AS, et al. Adverse prognostic significance of KIT mutations in adult acute myeloid leukemia with inv(16) and $t(8 ; 21)$ : a Cancer and Leukemia Group B Study. J ClinOncol. 2006;24:3904 -3911.

[88] Peter L. Greenberg, Sandra J. Lee, Ranjana Advani, Martin S. Tallman, Branimir I. Sikic, Louis Letendre, Kathleen Dugan, Bert Lum, David L. Chin, Gordon Dewald, Elisabeth Paietta, John M. Bennett, and Jacob M. Rowe. Mitoxantrone, Etoposide, and Cytarabine With or Without Valspodar in Patients With Relapsed or Refractory Acute Myeloid Leukemia and High-Risk Myelodysplastic Syndrome: A Phase III Trial (E2995). J Clin Oncol 2004;22:1078-1086.

[89] Preisler H, Davis RB, Kirshner J, et al. Comparison of three remission induction regimens and two postinduction strategies for the treatment of acute nonlymphocyticleukemia: a cancer and leukemia group B study. Blood. 1987;69:1441-1449.

[90] Raffoux E, Rousselot P, Poupon J, et al. Combined treatment with arsenic trioxide and all-trans-retinoic acid in patients with relapsed acute promyelocyticleukemia. J ClinOncol. 2003;21:2326-2334.

[91] Rowe JM. Optimal induction and post-remission therapy for AML in first remission. Hematology Am SocHematolEduc Program. 2009:396-405.

[92] Rozenfeld-Granot G, Toren A, Amariglio N, Brok-Simoni F, Rechavi G. Mutation analysis of the FAS and TNFR apoptotic cascade genes in hematological malignancies. Exp Hematol. 2001;29(2):228-33. 
[93] Sachs L. The control of hematopoiesis and leukemia: from basic biology to the clinic. Proc. Natl. Acad. Sci. USA. 1996; 93, 4742- 4749.

[94] Sanz MA, Grimwade D, Tallman MS, et al. Guidelines on the management of acute promyelocyticleukemia: recommendations from an expert panel on behalf of the European LeukemiaNet. Blood. Prepublished on September 23, 2008.

[95] Schiller G, Gajewski J, Nimer S, et al. A randomized study of intermediate versus conventional-dose cytarabine as intensive induction for acute myelogenous leukaemia. Br J Haematol. 1992;81:170 -177.

[96] Schlenk RF, Dohner K, Krauter J, et al. Mutations and treatment outcome in cytogenetically normal acute myeloid leukemia. N Engl J Med. 2008;358:1909 -1918.

[97] Schnittger S, Kohl TM, Haferlach T, et al. KIT-D816 mutations in AML1-ETO-positive AML are associated with impaired event-free and overall survival. Blood. 2006;107:1791-1799.

[98] Sheikh MS, Burns TF, Huang Y, Wu GS, Amundson S, Brooks KS, FornaceJr AJ, elDeiry WS. p53-dependent and -independent regulation of the death receptor KILLER/DR5 gene expression in response to genotoxic stress and tumor necrosis factor alpha. Cancer Res 1998; 58:1593-1598.

[99] Shigeno M, Nakao K, Ichikawa T, Suzuki K, Kawakami A, Abiru S, Miyazoe S, Nakagawa Y, Ishikawa H, Hamasaki K, Nakata K, Ishii N, Eguchi K. Interferonalpha sensitizes human hepatoma cells to TRAIL-induced apoptosis through DR5 upregulation and NF-kappa B inactivation. Oncogene 2003; 22:1653-1662.

[100] Schimmer AD, Herr W, Hänel M, Borthakur G, Frankel A, Horst HA, Martin S, Kassis J, Desjardins P, Seiter K, Fiedler W, Noppeney R, Giagounidis A, Jacob C, Jolivet J, Tallman MS, Koschmieder S. Addition of AEG35156 XIAP Antisense Oligonucleotide in Reinduction Chemotherapy Does Not Improve Remission Rates in Patients With Primary Refractory Acute Myeloid Leukemia in a Randomized Phase II Study. Clin Lymphoma Myeloma Leuk. 2011;11(5):433-8.

[101] Solary E, Witz F, Caillot D, et al. Combination of quinine as a potential reversing agent with mitoxantrone and cytarabine for the treatment of acute leukemias: a randomized multicentric study. Blood. 1996;88:1198-1205.

[102] Soignet SL, Frankel SR, Douer D, et al. United States multicenter study of arsenic trioxide in relapsed acute promyelocyticleukemia. J ClinOncol. 2001;19:3852-3860.

[103] Stadheim TA, Saluta GR, Kucera GL. Role of c-Jun N-terminal kinase/p38 stress signaling in 1-beta-D-arabinofuranosylcytosine-induced apoptosis. BiochemPharmacol 2000; 59(4):407-418.

[104] Stegmaier K, Corsello SM, Ross KN, Wong JS, Deangelo DJ, Golub TR. Gefitinib induces myeloid differentiation of acute myeloid leukemia. Blood. 2005;106:28412848.

[105] Stelljes M, Beelen DW, Braess J, Sauerland MC, Heinecke A, Berning B, Kolb HJ, Holler E,Schwerdtfeger R, Arnold R, Spiekermann K, Müller-Tidow C, Serve HL, Silling G, HiddemannW,Berdel WE, Büchner T, Kienast J; German AML Cooperative Group (AMLCG). Allogeneic transplantation as post-remission therapy for cytogenetically high-risk acute myeloid leukemia: landmark analysis from a single prospective multicenter trial. Haematologica. 2011;96(7):972-979. 
[106] Styczynski J, Wysocki m, Debski R et al. Predictive value of multidrug resistance proteins and cellular drug resistance in childhood relapsed acute lymphoblastic leukemia. J Cancer Res ClinOncol. 2007;133(11):875-93.

[107] Svingen PA, Karp JE, Kraiewski S, Mesner PW, Gore SD, Burke PJ, et al. Evaluation of Apaf- 1 and procaspases-2, $-3,-7$, and -9 as potential prognostic markers in acute leukaemia. Blood 2000;96:3922-3931.

[108] Swerdlow SH, Campo E, Harris NL, et al, eds.WHO Classification of Tumours of Haematopoietic and Lymphoid Tissues. Lyon, France: IARC Press; 2008.

[109] Tallman MS, Lee S, SikicBl et al. Mitoxantrone, etoposide and cytarabine plus cyclosporine for patients with relapse or refractory acute myeloid leukaemia: an Eastern Cooperative Oncology Group pilot study. Cancer .1999;85:358-367.

[110] Tanaka H, Matsumura I, Nakajima K, Daino H, Sonoyama J, Yoshida H, Oritani K, Machii T, Yamamoto M, Hirano T and Kanakura Y. GATA-1 blocks IL-6-induced macrophage differentiation and apoptosis through the sustained expression of cyclin D1 and bcl-2 in a murine myeloid cell line M1. Blood. 2000; 95, 1264-1273.

[111] Testa U and Riccioni R. Deregulation of apoptosis in acute myeloid leukemia. Haematologica 2007; 92:81-94

[112] Tourneur L, Delluc S, Lévy V, Valensi F, Radford-Weiss I, Legrand O, Vargaftig J, BoixC,Macintyre EA, Varet B, Chiocchia G, Buzyn A. Absence or low expression of fas-associated protein with death domain in acute myeloid leukemia cells predicts resistance to chemotherapy and poor outcome. Cancer Res. 2004 Nov 1;64(21):8101-8108.

[113] Tucker SJ, Rae C, Littlejohn AF, Paul A, MacEwan DJ. Switching leukemia cell phenotype between life and death. ProcNatlAcadSci U S A 2004; 101(35):12940-5.

[114] Van del Heuvel E, van der Holt B, Burnette AK et al. CD34-related coexpression of MDR1 and BCRP indicates a clinically resistant phenotype in patients with acute myeloid leukemia (AML) of older age. Ann Hematol. 2007;86(5):329-337.

[115] van Geelen CM, de Vries EG, Le TK, van Weeghel RP, de Jong S. Differential modulation of the TRAIL receptors and the CD95 receptor in colon carcinoma cell lines. Br J Cancer. 2003;89(2):363-373.

[116] Vardiman JW, Thiele J, Arber DA, et al. The 2008 revision of the World Health Organization (WHO) classification of myeloid neoplasms and acute leukemia: rationale and important changes. Blood. 2009;114:937-951.

[117] Wattel E, Preudhomme C, Hecquet B, et al. p53 mutations are associated with resistance to chemotherapy and short survival in hematologic malignancies. Blood. 1994;84:3148-3157.

[118] Wen LX, Hui LS, Zhong FA et al. Combination of tetrandrine as a potential-reversing agent with daunorubicin, etoposide and cytarabine for the treatment of refractory and relapsed acute myelogenousleukemia. Leuk Res. 2006;30(4):407-413.

[119] Wen J, Ramadevi N, Nguyen D, Perkins C, Worthington E, Bhalla K. Antileukemic drugs increase death receptor 5 levels and enhance Apo-2L-induced apoptosis of human acute leukemia cells. Blood 2000; 96:3900-3906.

[120] Weick JK, Kopecky KJ, Appelbaum FR, et al. A randomized investigation of high-dose versus standard-dose cytosine arabinoside with daunorubicin in patients with previously untreated acute myeloid leukemia: a Southwest Oncology Group study. Blood. 1996;88:2841-2851. 
[121] Wu GS, Burns TF, McDonald IIIrd ER, Jiang W, Meng R, Krantz ID, Kao G, Gan DD, Zhou JY, Muschel R, Hamilton SR, Spinner NB, Markowitz S, Wu G, el-Deiry WS. KILLER/DR5 is a DNA damage-inducible p53-regulated death receptor gene. Nat Genet. 1997; 17:141-143.

[122] Yates JW, Wallace HJ Jr, Ellison RR, Holland JF. Cytosine arabinoside (NSC-63878) and daunorubicin (NSC-83142) therapy in acute nonlymphocyticleukemia. Cancer Chemother Rep. 1973;57:485 - 488.

[123] Yu R, Shtil AA, Tan TH, Roninson IB, Kong AN. Adriamycin activates c-Jun Nterminal kinase in human leukemia cells: a relevance to apoptosis. Cancer Letter 1999; 107(1):73-81. 


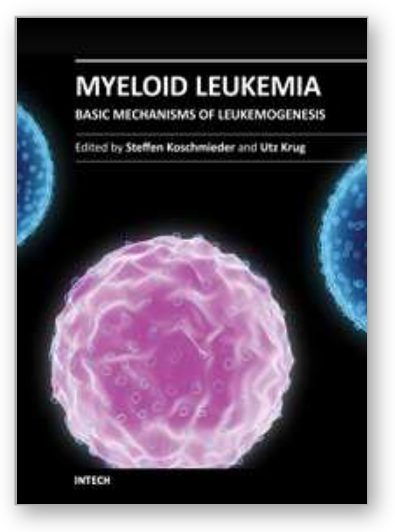

\author{
Myeloid Leukemia - Basic Mechanisms of Leukemogenesis \\ Edited by Dr Steffen Koschmieder
}

ISBN 978-953-307-789-5

Hard cover, 484 pages

Publisher InTech

Published online 14, December, 2011

Published in print edition December, 2011

The current book comprises a series of chapters from experts in the field of myeloid cell biology and myeloid leukemia pathogenesis. It is meant to provide reviews about current knowledge in the area of basic science of acute $(A M L)$ and chronic myeloid leukemia $(C M L)$ as well as original publications covering specific aspects of these important diseases. Covering the specifics of leukemia biology and pathogenesis by authors from different parts of the World, including America, Europe, Africa, and Asia, this book provides a colorful view on research activities in this field around the globe.

\title{
How to reference
}

In order to correctly reference this scholarly work, feel free to copy and paste the following:

Maha Abdullah and Zainina Seman (2011). Apoptosis and Apoptosis Modulators in Myeloid Leukemia, Myeloid Leukemia - Basic Mechanisms of Leukemogenesis, Dr Steffen Koschmieder (Ed.), ISBN: 978-953-307-789-5, InTech, Available from: http://www.intechopen.com/books/myeloid-leukemia-basic-mechanisms-ofleukemogenesis/apoptosis-and-apoptosis-modulators-in-myeloid-leukemia

\section{INTECH}

open science | open minds

\section{InTech Europe}

University Campus STeP Ri

Slavka Krautzeka 83/A

51000 Rijeka, Croatia

Phone: +385 (51) 770447

Fax: +385 (51) 686166

www.intechopen.com

\section{InTech China}

Unit 405, Office Block, Hotel Equatorial Shanghai

No.65, Yan An Road (West), Shanghai, 200040, China

中国上海市延安西路65号上海国际贵都大饭店办公楼 405 单元

Phone: +86-21-62489820

Fax: $+86-21-62489821$ 
(C) 2011 The Author(s). Licensee IntechOpen. This is an open access article distributed under the terms of the Creative Commons Attribution 3.0 License, which permits unrestricted use, distribution, and reproduction in any medium, provided the original work is properly cited. 